RESEARCH ARTICLE

\title{
Sucrose metabolism during fruit development in Coffea racemosa
}

\author{
C. Geromel ${ }^{1}$, L.P. Ferreira ${ }^{2}$, A. Bottcher ${ }^{1}$, D. Pot ${ }^{2,4}$, L.F.P. Pereira ${ }^{3}$, T. Leroy ${ }^{4}$, L.G.E. Vieira ${ }^{2}$, \\ P. Mazzafera ${ }^{1}$ \& P. Marraccini $i^{2,4}$ \\ 1 UNICAMP University of Campinas, Biology Institute, Campinas, São Paulo state, Brazil \\ 2 IAPAR, Agronomy Institute of Paraná, Laboratory of Biotechnology, Londrina, Paraná state, Brazil \\ 3 EMBRAPA Café, Agronomy Institute of Paraná, Laboratory of Biotechnology, Londrina, Paraná state, Brazil \\ 4 CIRAD Centre de Coopération Internationale en Recherche Agronomique pour le Développement, UMR DAP, Montpellier, France
}

\begin{abstract}
Keywords
Coffee bean development; coffee; Rubiaceae; sucrose metabolism; sucrose synthase.

\section{Correspondence}

P. Marraccini, EMBRAPA, Cirad, UMR DAP, Center of Genetic Resources and Biotechnology, Parque Estação Biológica, CP 02372, 70770-900 Brasilia (DF), Brazil.

Email: marraccini@cirad.fr
\end{abstract}

Received: 18 June 2007; revised version accepted: 10 September 2007.

doi:10.1111/j.1744-7348.2007.00199.x

\begin{abstract}
Sucrose is one of the compounds in the raw coffee bean that has been identified as an important precursor of coffee flavour and aroma. In order to increase our knowledge of sucrose metabolism in coffee species, sucrose and reducing sugar content were investigated in the fast fruit-ripening coffee species Coffea racemosa. Fruits were harvested regularly from anthesis, until the point of complete fruit maturation and tissue development, followed by measurement of fruit tissue weight. Pericarp was the most abundant tissue, and always represented around $70-80 \%$ of fruit fresh weight. The perisperm present in young fruits was rapidly replaced by the endosperm at around 40 days after flowering (DAF). In the latter tissue, total and reducing sugars decreased during development. However, sucrose content was maintained at a relatively high level throughout fruit development, with a peak at 40 DAF that coincided with the highest level of sucrose synthase (SUS) activity detected in this tissue. For all endosperm developmental stages analysed, very low invertase activity was observed, suggesting a limited role for this enzyme in sucrose metabolism. Northern blot experiments using SUS1 and SUS2 cDNA sequences from Coffea arabica as probes were carried out to study the expression of SUS-encoding genes. The SUS1 transcripts of C. racemosa overlapped with the peak of SUS activity in the endosperm, whereas SUS2 transcripts accumulated mainly during the latest stages of endosperm development. Altogether, these results suggest that the SUSI isoform of SUS is essential for sucrose accumulation in the fruits of C. racemosa.
\end{abstract}

\section{Introduction}

Coffea racemosa Lour. (Rubiaceae) originates from East Africa and is characterised by abundant branching, high leaf drop during the dry season and rapid fruit maturation (Guerreiro Filho, 1992). C. racemosa produces a pale coloured aromatic beverage that is low in caffeine (Silva, 1956; Mazzafera, 1990) and of medium quality (Chevalier, 1947). It is consumed locally in several countries in East
Africa (e.g. Mozambique), but is not commercially exploited as a result of its low productivity. Like most Coffea species, C. racemosa is diploid $(2 n=2 x=22)$ and allogamous, with several self-incompatibility alleles (Silva, 1956; Mônaco \& Carvalho, 1972). This species has several other interesting agronomical characteristics, which have been transferred to commercial coffee varieties by traditional breeding programmes. Because it can be easily crossed with Coffea arabica ( $2 n=4 x=44$ chromosomes), 
the use of C. racemosa in coffee breeding programmes is of particular interest for the development of new coffee hybrids that are resistant to biotic and abiotic stresses while maintaining high beverage quality (Guerreiro Filho et al., 1991). C. racemosa is highly resistant to the leaf miner (Perileucoptera coffeella) and to several Meloidogyne spp. and is weakly infected by leaf rust (Hemileia vastatrix) under field conditions (Guerreiro Filho, 1992, 2006). It also presents a tolerance to drought and high temperatures, which is mainly explained by its deep root system. At the genomic level, C. racemosa was also one of the three coffee species used for the Brazilian coffee genome initiative (Vieira et al., 2006). More than 15000 expressed sequence tags (ESTs) of C. racemosa were generated from fruit cDNA libraries and clustered into 919 contigs and 3107 singletons. Today, these ESTs are the only ones from this species sequenced in the world.

The complete development of C. racemosa fruits is achieved over a shorter period (60-110 days) than in C. arabica (180-250 days) and Coffea canephora (270330 days) (Wormer, 1964; Berthaud \& Charrier, 1988). Compared with $C$. arabica fruits, those of C. racemosa are relatively small (8-11 mm length, 4-6 mm width), black coloured at maturity and very aromatic (Chevalier, 1947). They also have a thick and aqueous mesocarp (pulp), a fine endocarp and a small, yellow-coloured endosperm (Carvalho, 1967). The composition of the C. racemosa endosperm (bean) has not been studied in depth (Lopes, 1974), but recent studies report a trigonelline content close to $1 \%$ of dry weight (DW), a level intermediate to that of C. arabica $(1.13 \%)$ and C. canephora $(0.82 \%)$ (Campa et al., 2004). Caffeine content is relatively low, varying from $0.8 \%$ to $1 \%$ (Lopes, 1974; Mazzafera \& Magalhães, 1991; Mazzafera et al., 1991). In the search for genetic factors controlling beverage quality, particular attention has been given to the sucrose content in coffee endosperm, which is considered to be a key precursor of flavour and aroma (Guyot et al., 1996; Casal et al., 2000; Leroy et al., 2006). In C. racemosa, the average sucrose content has been estimated at $6.44 \%$ DW, closer to that of C. canephora $(6.10 \%)$, compared with that of C. arabica (9.32\%) (Guyot et al., 1988; Ky et al., 2001; Campa et al., 2004).

Sucrose and its cleavage products (glucose and fructose) are also central molecules controlling the development of sink organs (Sturm \& Tang, 1999; Koch, 2004). Sucrose transport from source leaves into sink organs is controlled by 'sink strength', which is defined as the ability of these organs to attract sucrose (Ho, 1988). In this scheme, sucrose synthase (SUS: EC 2.4.1.13) is often the predominant sucrolytic activity, providing assimilated carbon (i.e. uridine diphosphate-glucose) for respiration, starch synthesis and cell wall synthesis (Wang et al., 1993; Fu \& Park, 1995; Weber et al., 1997). However, an increase in SUS activity associated with sucrose accumulation has been reported in several fruits, such as peach, citrus fruits and muskmelon (Lingle \& Dunlap, 1987; Moriguchi et al., 1990; Hubbard et al., 1991; Komatsu et al., 2002). Initial studies of sugar metabolism, sucrosemetabolising enzymes and genes coding for these enzymes in coffee were recently published (Leroy et al., 2005; Geromel et al., 2006). They showed that SUS exists as two isoforms, encoded by the CaSUS1 and CaSUS2 genes, which are phylogenetically distinct and differentially expressed during endosperm development. In addition, the SUS2 isoform was identified as one of the main enzymes controlling sucrose accumulation in coffee beans because the expression of its corresponding gene overlapped with the peaks in SUS activity and sucrose accumulation observed at maturation.

The present study was conducted to increase our basic knowledge of sucrose metabolism during the development of fruits in coffee species. Concentrations of sucrose, total and reducing sugars, as well as the activities of sucrose-metabolising enzymes, were monitored in the endosperm throughout fruit development of the fastripening C. racemosa. Relationships between sucrose and reducing sugar contents, the activities of sucrosemetabolising enzymes and the expression of SUS genes are discussed and compared with the information already available for C. arabica.

\section{Materials and methods}

\section{Plant material}

Fruits were collected from a 15-year-old plant of C. racemosa maintained in the living coffee collection at IAPAR (Instituto Agronômico do Paraná, Londrina, PR, Brazil). Fruits were harvested every 2 weeks after the main flowering (27 October 2004) until full ripening (3 January 2005). The phenological stages were as follows: stage 1 [12 days after flowering (DAF)], small fruits with seed mainly formed of aqueous perisperm; stage 2 (26 DAF), aqueous endosperm tissue progressively replacing the perisperm; stage 3 (40 DAF), milky endosperm; stage 4 (54 DAF), hard white endosperm with the remaining perisperm forming a thin green pellicle surrounding the endosperm and stage 5 (68 DAF), ripening fruits with pericarps turning to purple. To ensure developmental synchrony of harvested fruits, cross-sections were made to visually inspect the tissues that were separated, and the tissues were immediately frozen in liquid nitrogen and stored at $-80^{\circ} \mathrm{C}$ for further analysis. 


\section{Fresh weight evaluations}

Fresh weights $(\mathrm{FWs})$ were evaluated from $120(3 \times 40)$ fruits at $12 \mathrm{DAF}$, from $60(3 \times 20)$ fruits at $26 \mathrm{DAF}$ and from 30 fruits $(3 \times 10)$ for the subsequent harvests. Tissue (perisperm, endosperm and pericarp) development was followed by weighting separated tissues obtained from $30(3 \times 10)$ fruits.

\section{Sugar determination and enzyme analysis}

Fruit tissues were lyophilised, ground with a mortar and pestle and extracted with $80 \%$ ethanol (300 mg per $1 \mathrm{~mL}$ ) in a Polytron homogeniser. Extraction proceeded for $30 \mathrm{~min}$ at $75^{\circ} \mathrm{C}$ in sealed tubes and the supernatant was obtained after centrifugation. The extraction was carried out three times with the same volume of ethanol, and the combined supernatants were used for the analysis of total soluble sugar, sucrose and reducing sugar (Geromel et al., 2006). Acid invertase (AI) was assayed in the direction of sucrose cleavage and SUS was assayed in the direction of sucrose synthesis, as previously described (Geromel et al., 2006). Results of sugar contents are expressed in $\mathrm{mg} \mathrm{g}^{-1}$ of dry weight (DW). For enzymatic activities, protein content was determined with a ready-to-use Bradford (1976) reagent (Bio-Rad, Hercules, CA, USA) and is expressed in nkat $\mathrm{mg}^{-1}$ protein. In both cases, results are given as mean \pm SD of three independent extractions. Extracts obtained for enzyme analysis were used in Western blot experiments. The proteins were separated by $10 \%(\mathrm{w} / \mathrm{v})$ polyacrylamide gel electrophoresis and stained with Coomassie brilliant blue to demonstrate equal loading of proteins (data not shown). Proteins were further transferred to polyvinylidene difluoride membranes using a Mini protean electrophoresis apparatus (Bio-Rad). The membranes were probed with a polyclonal antibody directed against SUS from Pisum sativum using the protocol described by Déjardin et al. (1997) and developed using an antirabbit secondary antibody conjugated with alkaline phosphatase.

\section{Expression analysis}

Total RNA was extracted from frozen fruits $\left(-80^{\circ} \mathrm{C}\right)$, as previously described (Marraccini et al., 2001). Total RNA $(15 \mu \mathrm{g})$ was denatured in $12.55 \mathrm{M}$ formamide, $2.2 \mathrm{M}$ formaldehyde and $20 \mathrm{mM}$ 3-( $N$-morpholino)-propanesulfonic acid (MOPS) buffer, pH 7.0 [also containing $5 \mathrm{mM} \mathrm{Na}$ acetate and $0.1 \mathrm{mM}$ ethylenediamine tetraacetic acid (EDTA)] at $65^{\circ} \mathrm{C}$ for $5 \mathrm{~min}$ and fractionated on a $1.2 \%(\mathrm{w} / \mathrm{v})$ agarose gel containing $2.2 \mathrm{~m}$ formaldehyde in MOPS buffer. After transfer to nylon membranes (Amersham Biosciences, São Paulo, SP, Brazil), filters were prehybridised and hybridised as described for the use of the Ultrahyb ${ }^{\mathrm{TM}}$ buffer (Ambion, USA). Probes used corresponded to partial sequences of CaSUS1 (GenBank accession number AM087674) and CaSUS2 (GenBank accession number AM087675) cDNAs from C. arabica coding, respectively, for isoforms 1 and 2 of SUS (Geromel et al., 2006) were labelled by random priming with $50 \mu \mathrm{Ci}$ of $\left[\alpha^{32} \mathrm{P}\right] \mathrm{dCTP}$ (Amersham Biosciences) according to Sambrook et al. (1989). After hybridisation, membranes were washed under stringent conditions $[2 \times$ 15 min in $2 \times$ sodium chloride-sodium citrate buffer (SSC), $0.1 \%$ sodium dodecyl sulfate (SDS) at $65^{\circ} \mathrm{C}$ and $2 \times 15 \mathrm{~min}$ in $0.1 \times \mathrm{SSC}, 0.1 \%$ SDS at $65^{\circ} \mathrm{C}$ ) and exposed to Kodak X-Omat AR-5 film (Kodak, São Paulo, SP, Brazil) with an intensifying screen. Amounts of RNA samples loaded were controlled by loading equal abundances of $18 \mathrm{~S}$ and $26 \mathrm{~S}$ rRNAs on gels stained with ethidium bromide.

\section{Results}

\section{Fruit development}

Under our field conditions, fruits of $C$. racemosa completed their development in 68 DAF (Fig. 1). The fruit growth curve, as measured by FW, exhibited a biphasic course with a first peak at 12-26 DAF and a second between 40 and $54 \mathrm{DAF}$ (Fig. 2A). During fruit development, the pericarp was the most abundant tissue, representing almost $70-80 \%$ of total fruit FW (Fig. 2B). The perisperm tissue, originating from the maternal nucleus tissue, disappeared rapidly between 12 and 40 DAF, concomitant with a rapid expansion of the endosperm that occurred between 26 and 40 DAF. At this time, the endosperm occupied the entire locule space and its size was equal to that of the mature stage.

\section{Sugar content in developing fruits}

Sugar (total soluble sugars, sucrose and reducing sugars) content was measured in each tissue during fruit development (Fig. 3A-C). After a decrease at 26 DAF, total soluble sugar content increased regularly in the pericarp during maturation, reaching $448 \mathrm{mg} \mathrm{g}^{-1} \mathrm{DW}$ at maturity (68 DAF) (Fig. 3A). Sucrose content represented one third of the total sugars in the pericarp at 12 DAF and less than $20 \%$ at maturity (Fig. 3B). This is because of a sudden accumulation of reducing sugars that occurred during the 2 weeks preceding the harvest (Fig. 3C).

In the perisperm, total sugars accumulated up to $130 \mathrm{mg} \mathrm{g}^{-1} \mathrm{DW}$ at $26 \mathrm{DAF}$ and decreased as this tissue gradually disappeared. The levels of sucrose and reducing sugar content in this tissue followed this pattern, with sucrose content always representing around $40 \%$ of total sugars. The endosperm had a high content of 

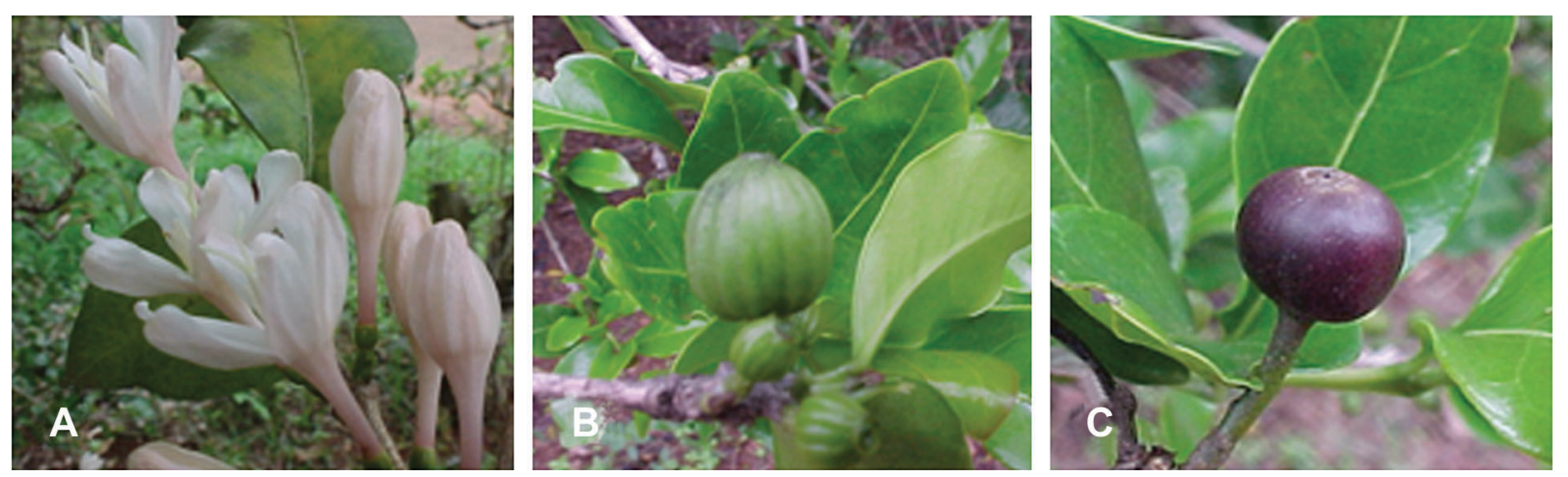

Figure 1 Development of Coffea racemosa fruits: flower at anthesis (A), green fruit at around 40 DAF (B) and fruit at maturity, around 68 DAF (C). Photographs were provided by Dr Oliveiro Guerreiro Filho, Instituto Agronômico de Campinas (IAC), Campinas, SP, Brazil.

soluble sugars (195 $\mathrm{mg} \mathrm{g}^{-1} \mathrm{DW}$ ) at 26 DAF. Throughout its development, these soluble sugars decreased continuously. This decline was mainly related to reducing sugars, with only trace levels being detected at the mature stage (Fig. 3C). In contrast to observations in C. arabica and C. canephora (Rogers et al., 1999), the decrease in reducing sugars was not accompanied by a concomitant increase in sucrose. Sucrose concentrations appeared to be relatively high during endosperm maturation, reaching a maximum value $\left(90 \mathrm{mg} \mathrm{g}^{-1} \mathrm{DW}\right)$ at $40 \mathrm{DAF}$ and declining to $67.9 \mathrm{mg} \mathrm{g}^{-1}$ at the mature stage. At this time, sucrose represented approximately $100 \%$ of total soluble sugars.

Enzymatic activities in the endosperm during fruit development

Acid invertase and SUS enzyme activities were measured to determine if they might be correlated with variations in the amounts of soluble sugars. Protein extracts were prepared during endosperm maturation from 26 to $68 \mathrm{DAF}$ (Fig. 4A). Low AI activity was observed in developing endosperm during all the phenological stages analysed. However, SUS activity showed a peak $\left(3.02 \mathrm{nkat} \mathrm{mg}^{-1}\right.$ protein) at 40 DAF that coincided with the rapid expansion of the endosperm. This activity declined steadily towards the end of maturation such that it was barely detectable in mature fruits.

A Western blot analysis of endosperm proteins was also carried out using antibodies against the major SUS isoform of pea teguments and corresponding to the protein product of the PSSUSI (AJ012080) gene (C. Rochat, personal communication). Under semidenaturing electrophoresis conditions, a SUS isoform (estimated molecular weight of $90.0 \mathrm{kDa}$ ) was detected in protein extracts with a peak at $40 \mathrm{DAF}$ (stage 3); the isoform was detected in lesser amounts at 26 and $54 \mathrm{DAF}$ (Fig. 4B). It is worth noting that the antibodies also reacted with another SUS isoform of lower molecular weight, which was revealed by a faint band at 26 and 54 DAF. However, no antibody cross-reaction was detected near maturation at 68 DAF.
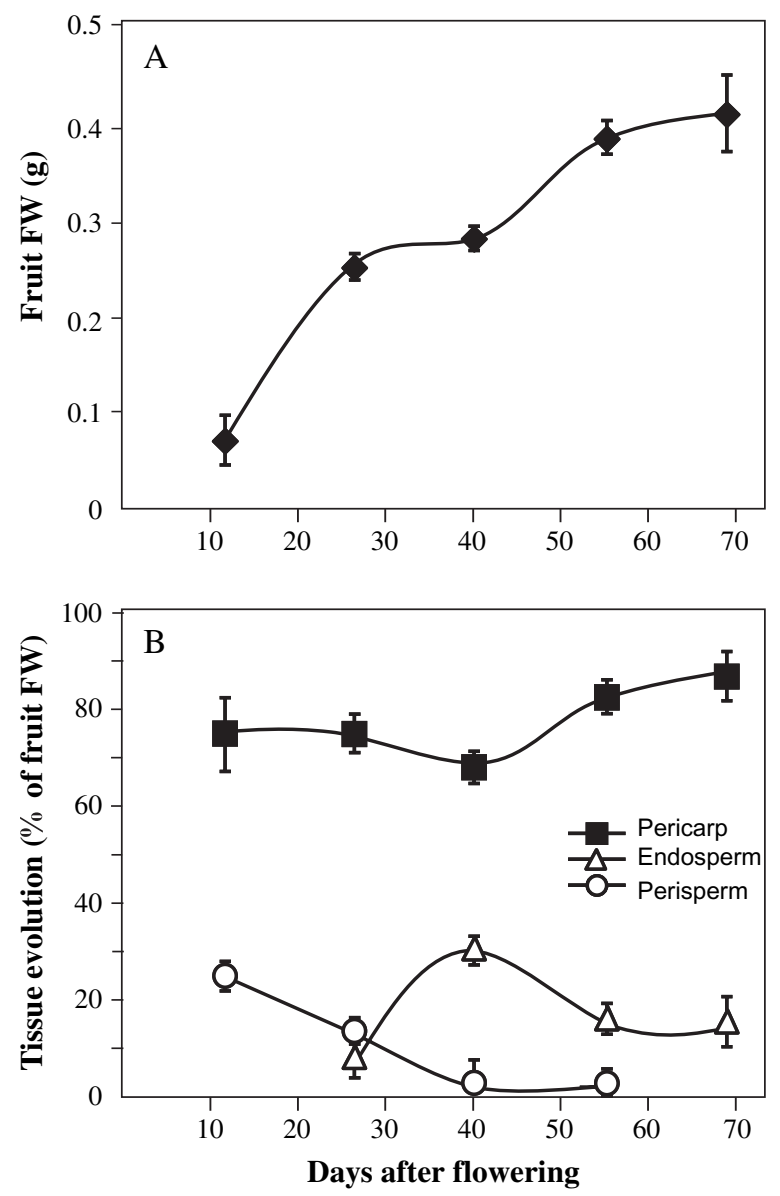

Figure 2 Weight of tissues during Coffea racemosa fruit ripening. (A) Fresh weights (FW) are given in grams for the entire cherry ( $)$. (B) Evolution of pericarp $(\square)$, perisperm $(O)$ and endosperm $(\Delta)$ tissues, expressed as a percentage of cherry FW. Error bars indicate standard deviations $(n=3)$. 

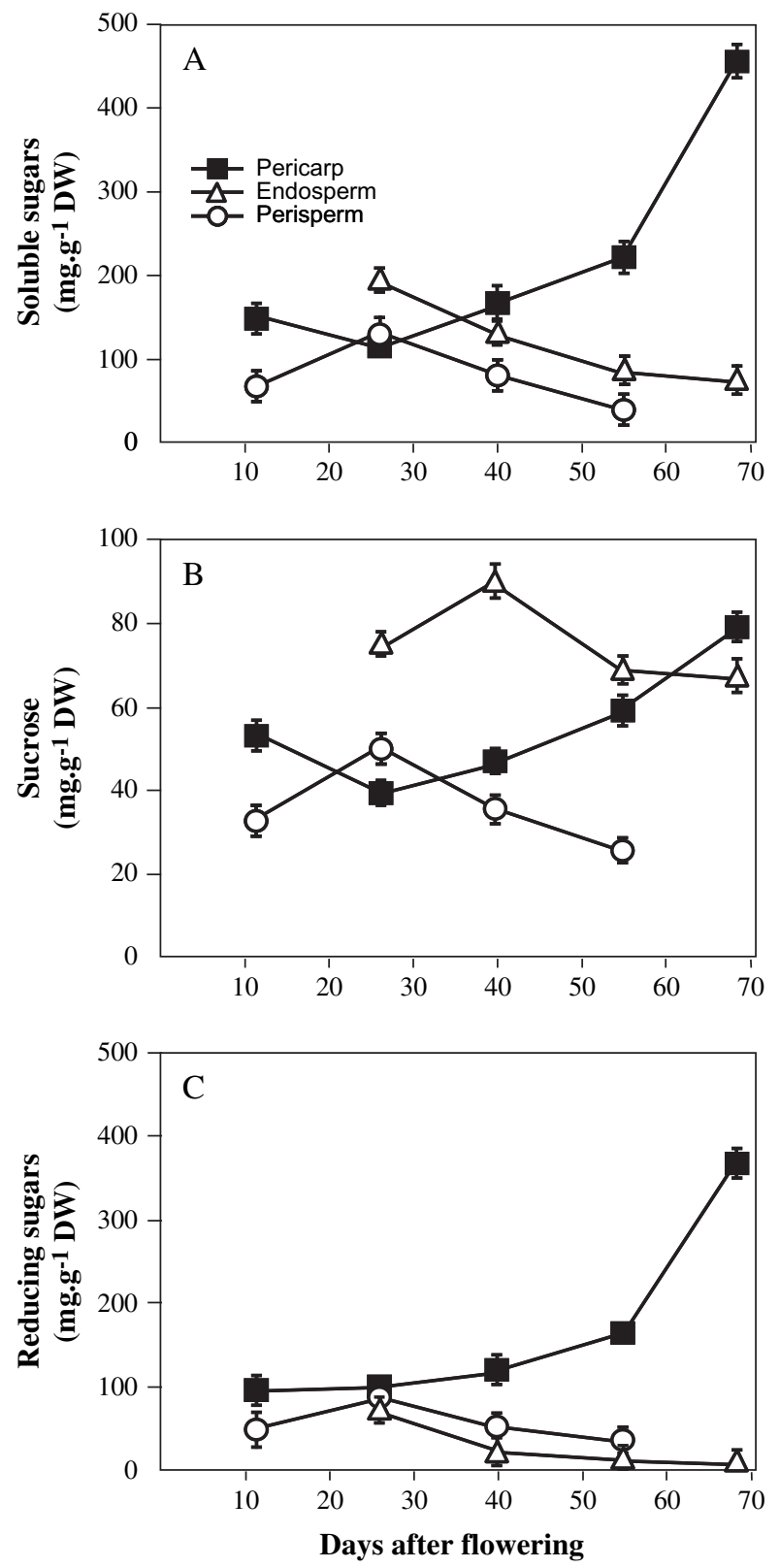

Figure 3 Total soluble sugar (A), sucrose (B) and reducing sugar (C) contents were measured in pericarp $(\square)$, perisperm $(\mathbf{O})$ and endosperm $(\Delta)$ tissues separated from the fruits of Coffea racemosa during ripening. Values are given in $\mathrm{mg} \mathrm{g}^{-1}$ of dry weight (DW). Error bars indicate standard deviations of repetitions $(n=3)$.

Expression of SUS genes in the endosperm during fruit development

To analyse the expression of the SUS-encoding genes of C. racemosa, total RNA from endosperm harvested between 26 to 68 DAF was hybridised with CaSUS1 and CaSUS2 probes from C. arabica (Geromel et al., 2006) (Fig. 4C). With CaSUS1 probe, transcripts of approxi-

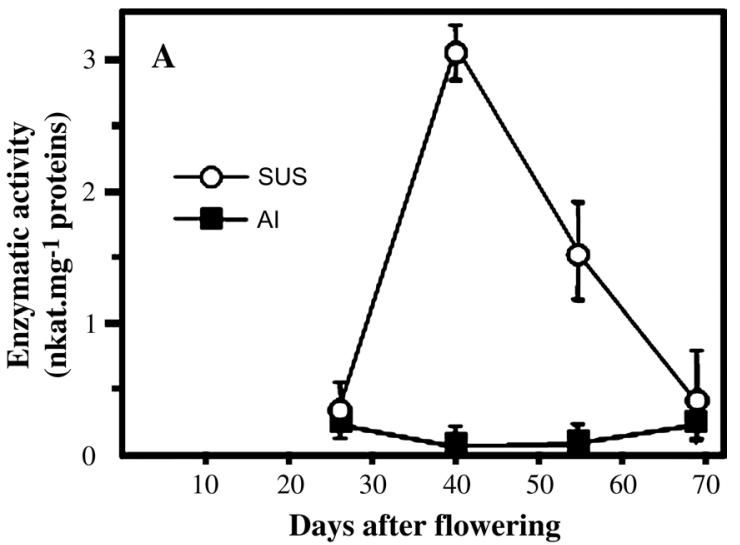

B $\begin{array}{llll}2 & 3 & 4 & 5\end{array}$

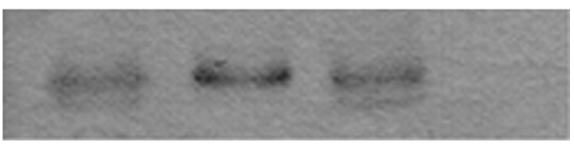

C 2 3 4 5

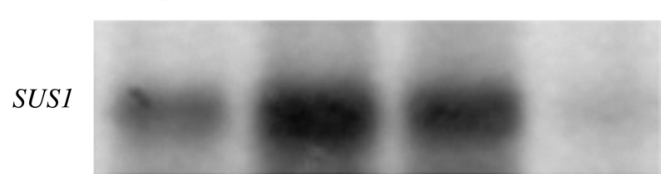

SUS2
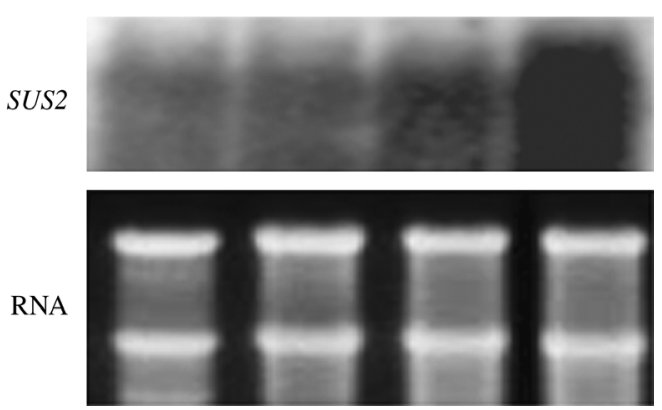

Figure 4 Sucrose synthase (SUS) and acid invertase (AI) activities in the endosperm of developing Coffea racemosa fruits. (A) Activities expressed in nkat $\mathrm{mg}^{-1}$ proteins. Error bars indicate standard deviations of repetitions $(n=3)$. (B) Western blot: proteins were extracted from developing endosperm (stage 2, 26 DAF; 3, $40 \mathrm{DAF} ; 4,54 \mathrm{DAF}$ and 5, $68 \mathrm{DAF}$ ) and probed with polyclonal antibodies raised against the abundant SUS isoform from Pisum sativum. (C) Expression of SUS1 and SUS2 genes of Coffea racemosa in developing endosperm. Total RNA (15 $\mu \mathrm{g})$ was isolated from endosperm at regular stages (given before) of fruit development and hybridised independently with labelled probes corresponding to SUS1 and SUS2 CDNAs from Coffea arabica. Total RNA stained with ethidium bromide was used to monitor the equal loading of the samples.

mately $2.9 \mathrm{~kb}$ were strongly detected in the endosperm between 26 and $54 \mathrm{DAF}$, with a peak at $40 \mathrm{DAF}$. With CaSUS2 probe, transcripts of approximately $2.9 \mathrm{~kb}$ were weakly revealed at the earliest stages of endosperm development (26-40 DAF) but accumulated at a high 
concentration at maturation (68 DAF). It is worth noting that at this time, the C. racemosa orthologous gene of CaSUSI was not expressed.

\section{Discussion}

Coffea racemosa fruits completed their development in 68 DAF. Despite this, the fruit growth curve exhibited a biphasic course that is commonly observed for other coffee species (Söndahl \& Baumann, 2001). In C. racemosa, the pericarp constitutes the predominant tissue during fruit development. As in other coffee species, the perisperm is present in young fruits and is rapidly replaced by the growing endosperm (De Castro \& Marraccini, 2006). The latest stages of fruit development are characterised by a significant increase in pericarp FW. In parallel, endosperm FW decreases drastically, characterising its intense dehydration during the latest stages of maturation (Eira et al., 2006). These results show that the main difference in tissue development between the C. racemosa and C. arabica species concerns with the ratio of pericarp/endosperm FW, which reaches 5.4 in C. racemosa (this study) and 2.0 in C. arabica (Geromel et al., 2006) at maturity.

Overall, sugar profiles in C. racemosa present some similarities with those observed in C. arabica, particularly in the pericarp, where sucrose and other sugars (total and reducing) accumulate late in development (Geromel et al., 2006). This is also the case in the perisperm, where reducing sugars and sucrose present a transient accumulation early in the development. As previously reported in C. arabica and C. canephora (Rogers et al., 1999), reducing sugar content decreased regularly throughout endosperm maturation of $C$. racemosa. However, sucrose levels appear relatively high and stable during endosperm development. This differs significantly from the situation observed in other coffee species, where sucrose contents were low in young endosperm and increased just before the harvest (Rogers et al., 1999; Geromel et al., 2006). In C. racemosa, sucrose content in mature beans was evaluated to be $6.8 \% \mathrm{DW}$, close to the value reported for this species (mean $6.44 \%$ with a range of $5.26-7.04 \%$ DW) by Campa et al. (2004). It is worth mentioning that lower contents of soluble and reducing sugars are observed in the pericarp exactly when sucrose has accumulated in the endosperm. This could characterise intensive sucrose exchange between these tissues. Vaast et al. (2006) estimated that pericarp photosynthesis may account for approximately $30 \%$ of the total carbon allocated in coffee fruits. The role of the pericarp in supplying photosynthates to developing coffee beans was also demonstrated by ${ }^{14} \mathrm{C}$ feeding experiments (Geromel et al., 2006).

At an enzymatic level, our results show low AI activity in the developing endosperm of C. racemosa, thus sug- gesting that this enzyme plays a limited role in the developing coffee beans of $C$. racemosa. SUS activity was noteworthy in the endosperm, with a peak at 40 DAF that declined towards maturation. It is worth mentioning that maximum SUS activity coincided perfectly with the highest sucrose content, with the rapid endosperm expansion and with the peak of SUS isoform identified by Western blot. In fact, this experiment reveals the presence of two SUS isoforms of similar molecular weights at 26 and 54 DAF but not at 40 DAF. This could reflect the presence of two closely related SUS1 isoforms with similar epitopes leading to cross-immunoreaction with the antibodies, as reported for the SUS-SHl and SUS1 isoforms of maize endosperm (Echt \& Chourey, 1985; Chourey et al., 1986). This could be tested using SUS isoform-specific antibodies (Duncan et al., 2006). SUS isoforms detected by Western blot could also characterise the same protein but in different post-translational modification states, implicating ubiquitination or SUMOylation (small ubiquitine-like modifier), for example as these would increase the molecular weight by 8 to $10 \mathrm{kDa}$ (Kurepa et al., 2003).

In developing seeds, the sucrose-cleaving activity of SUS has been correlated with starch synthesis (Winter $\delta$ Huber, 2000). As coffee endosperm has no apparent starch reserves (Rogers et al., 1999; Bradbury, 2001), this is not a likely role for SUS in developing coffee fruits. Our results are consistent with the action of SUS in controlling sucrose accumulation in the fruits of C. racemosa. They also present some important differences with those previously reported in C. arabica (Geromel et al., 2006). First, SUS activity is detected during endosperm expansion in C. racemosa but not in C. arabica. Second, the maximum SUS activity in C. racemosa was estimated to be 3.02 nkat mg $^{-1}$ proteins at $40 \mathrm{DAF}$, considerably lower than the peak in SUS activity (18.7 nkat $\mathrm{mg}^{-1}$ proteins) observed at $234 \mathrm{DAF}$ in C. arabica. It is tempting to speculate that the threshold differences in SUS activity observed between C. racemosa and C. arabica are responsible for the differences in sucrose level in the mature beans of these species (Campa et al., 2004). A comparative study of SUS activity during fruit development in different coffee species with plants of the same age and cultivated under identical field conditions should clarify this point.

In C. arabica, two cDNAs (CaSUS1 and CaSUS2) coding for phylogenetically distinct isoforms of SUS have been sequenced (Geromel et al., 2006). Their corresponding genes presented different expression profiles during endosperm development, with CaSUS1 being expressed in the earliest stages, while CaSUS2 was exclusively expressed during maturation. The expression of SUSencoding genes in the developing endosperm of $C$. racemosa 
was observed using SUS1 and SUS2 sequences as specific probes. Northern blots carried out under stringent conditions revealed transcripts hybridising with the two probes tested. This demonstrates that C. racemosa contains orthologous genes highly similar to those cloned and sequenced in C. arabica. A search of C. racemosa sequences homologous to CaSUS1 and CaSUS2 cDNAs was made within the Brazilian Coffee Genome Project (Vieira et al., 2006). Twenty-two ESTs homologous (identity $\geq 97 \%$ ) to CaSUS1 cDNA were identified. After clusterisation, they form a partial contig of 1950 bp encoding a putative polypeptide of 334 amino acids that is 99\% identical to the CaSUS 1 protein (data not shown). However, C. racemosa ESTs related to the CaSUS2 cDNA were not found. This situation resembles the one observed during the screening of the Brazilian Coffee Genome Project, where only 18 CaSUS2-homologous ESTs were encountered within a total of 130792 ESTs from C. arabica (De Castro \& Marraccini, 2006). This small number of ESTs is unexpected considering the high expression level of this gene observed at the mature stage both in C. racemosa (this study) and C. arabica (Geromel et al., 2006). It could be explained by particular difficulties in reverse transcription of the corresponding mRNA or by an under-representation of ESTs specific of mature coffee fruits in the cDNA libraries of this project.

In C. racemosa, as in C. arabica, the SUS1 gene is expressed during endosperm expansion and the SUS2 gene is expressed at maturation. However, a profile comparison of gene expression and enzymatic activities in both species reveals some important differences. The first concerns SUS1, whose expression seems higher and more extended over endosperm development in C. racemosa than in C. arabica. In C. racemosa, SUS1 expression overlaps perfectly with the peak in SUS activity, whereas no SUS activity accompanies the presence of SUS2 transcripts. This is in contrast to the case observed in $C$. arabica, where the absence of SUS activity was found to coincide with CaSUS1 expression, leading to the conclusion that CaSUS2 protein was the SUS isoform controlling sucrose accumulation ('source' function) in mature beans (Geromel et al., 2006). Such discrepancies cannot be explained by methodological artefacts because strictly identical methods were used in both studies. Several lines of reasoning could explain the absence of SUS activity in the mature beans of C. racemosa. For example, it is possible that SUS2 transcripts are not translated, a situation that was observed for the Sh gene, coding for the SSI isoenzyme of SUS in maize seedlings subjected to anaerobic stress (McElfresh \& Chourey, 1988; Taliercio \& Chourey, 1989; Guglielminetti et al., 1996). This situation was also reported during tomato fruit development, where SUS mRNA and protein levels were not closely coupled (Wang et al., 1994). Even after translation, the SUS2 protein could require some posttranslational modifications to be activated. This has been reported in soybean, where sucrose-cleaving activity in root nodule organogenesis requires the binding of early nodulin (ENOD) 40 peptide A (Röhrig et al., 2004). SUS protein has also been shown to be subject to reversible phosphorylation, controlled either by calcium-dependent protein kinase (CDPK) or plant sucrose non-fermenting (SNF) 1-related (SnRK1) protein kinases (Huang \& Huber, 2001; Halford et al., 2003). Such post-translational modifications control SUS distribution between the cytosol, plasma membrane and actin cytoskeleton (Winter \& Huber, 2000). They may also act on SUS protein turnover and limit SUS amounts in soluble extracts (Hardin et al., 2003). In vitro translation experiments, as well as modified extraction procedures for proteins and immunolocalisation assays with SUS2-specific antibodies should clarify these points.

\section{Acknowledgements}

We are grateful to Dulcinéia Aparecida de Souza and Maria Letícia Bonatelli for assistance in the sugar and Western blot analysis, and to Oliveiro Guerreiro Filho (Instituto Agronômico de Campinas, SP, Brazil) for providing photographs of C. racemosa fruits. We also thank Christine Rochat (INRA, Versailles, France) for providing the polyclonal antibody serum against SUS from pea and Ladaslav Sodek for reviewing the text. This project was supported by the Brazilian Consortium for Coffee Research and Development (CBP\&D-Café). Pierre Marraccini and David Pot received financial support (DCSUR-BRE-4C5-008) from the French Embassy in Brazil. Clara Geromel received a student fellowship from CAPES-Brazil. Luiz Gonzaga Esteves Vieira and Paulo Mazzafera received a research fellowship from CNPq, Brazil.

\section{References}

Berthaud J., Charrier A. (1988) Genetic resources of Coffea. In Coffee, Vol. 4, Agronomy, pp. 1-42. Eds R.J. Clarke and R. Macrae. London: Elsevier Applied Science.

Bradbury A.G.W. (2001) Chemistry I: non-volatile compounds: carbohydrates. In Coffee: Recent Developments, pp. 1-17. Eds R.J. Clarke and O.G. Vitzthum. Oxford: Blackwell Science. Bradford M.M. (1976) A rapid and sensitive method for the quantitation of microgram quantities of proteins utilizing the principle of protein-dye binding. Analytical Biochemistry, 2, 248-254.

Campa C., Ballester J.F., Doulbeau S., Dussert S., Hamon S., Noirot M. (2004) Trigonelline and sucrose diversity in wild Coffea species. Food Chemistry, 88, 39-44. 
Carvalho A. (1967) Espécies e variedades. In Manual do cafeicultor, pp. 17-39. Eds E.A. Graner and C. Godoy Jr. São Paulo, Brazil: Universidade de São Paulo, Edições Melhoramentos.

Casal S., Oliveira M.B., Ferreira M.A. (2000) HPLC/diodearray to the thermal degradation of trigonelline, nicotinic acid and caffeine in coffee. Food Chemistry, 68, 481-485.

Chevalier A. (1947) Les caféiers du globe. III: Systématique des caféiers et faux caféiers. Maladies et insectes nuisibles. In Encyclopédie biologique, pp. 356. Ed P. Lechevalier. Paris, France.

Chourey P.S., Latham M., Still P.E. (1986) Expression of two sucrose synthase genes in endosperm and seedling cells of maize: evidence of tissue specific polymerization of protomers. Molecular and General Genetics, 203, 251-255.

De Castro R., Marraccini P. (2006) Cytology, biochemistry and molecular changes during coffee fruit development. Brazilian Journal of Plant Physiology, 18, 175-199.

Déjardin A., Rochat C., Maugenest S., Boutin J.-P. (1997) Purification, characterization and physiological role of sucrose synthase in the pea seed coat (Pisum sativum L.). Planta, 201, 128-137.

Duncan K.A., Hardin S.C., Huber S.C. (2006) The three maize sucrose synthase isoforms differ in distribution, localization, and phosphorylation. Plant and Cell Physiology, 47, 959-971.

Echt C.S., Chourey P.S. (1985) A comparison of two sucrose synthetase isozymes from normal and shrunken-1 maize. Plant Physiology, 79, 530-536.

Eira M.T.S., Da Silva E.A.A., De Castro R.D., Dussert S., Walters C., Bewley J.D., Hilhorst H.W.M. (2006) Coffee seed physiology. Brazilian Journal of Plant Physiology, 18, 149-163.

Fu H., Park W.D. (1995) Sink and vascular-associated sucrose synthase functions are encoded by different gene classes in potato. Plant Cell, 7, 1369-1385.

Geromel C., Ferreira L.P., Cavalari A.A., Pereira L.F.P., Guerreiro S.M.C., Pot D., Leroy T., Vieira L.G.E., Mazzafera P., Marraccini P. (2006) Biochemical and genomic analysis of sucrose metabolism during coffee (Coffea arabica) fruit development. Journal of Experimental Botany, 57, 3243-3258.

Guerreiro Filho O. (1992) Coffea racemosa Lour: une revue. Café Cacao Thé, 36, 171-186.

Guerreiro Filho O. (2006) Coffee leaf miner resistance. Brazilian Journal of Plant Physiology, 18, 109-117.

Guerreiro Filho O., Medina Filho H.P., Carvalho A. (1991) Fontes de resistência ao bicho-mineiro Perileucoptera coffeella em Coffea sp. Bragantia, 50, 45-55.

Guglielminetti L., Alpi A., Perata P. (1996) Shrunken-1encoded sucrose synthase is not required for the sucrose-ethanol transition in maize under anaerobic conditions. Plant Science, 119, 1-10.
Guyot B., Petnga E., Vincent J.C. (1988) Analyse qualitative d'un café, Coffea canephora var. Robusta, en fonction de la maturité. 1. Evolution des caractéristiques physiques, chimiques, organoleptiques. Café Cacao Thé, 32, 127-140.

Guyot B., Manez J.C., Perriot J.J., Giron J., Villain L. (1996) Influence de l'altitude et de l'ombrage sur la qualité des cafés Arabica. Plantations, Recherche, Développement, 3, 272-280.

Halford N.G., Hey S., Jhurreea D., Laurie S., McKibbin R.S., Zhang Y., Paul M.J. (2003) Dissection and manipulation of metabolic signalling pathways. Annals of Applied Biology, $142,25-31$.

Hardin S.C., Tang G.-Q., Scholz A., Holtgraewe D., Winter H., Huber S.C. (2003) Phosphorylation of sucrose synthase at serine 170: occurrence and possible role as a signal for proteolysis. The Plant Journal, 35, 588-603.

Ho L.C. (1988) Metabolism and compartmentation of imported sugars in sink organs in relation to sink strength. Annual Review of Plant Physiology and Plant Molecular Biology, 39, 355-378.

Huang J.-Z., Huber S. (2001) Phosphorylation of synthetic peptides by CDPK and plant SNF1-related protein kinase. Influence of proline and basic amino acid residues at selected positions. Plant and Cell Physiology, 42, 1079-1087.

Hubbard N.L., Pharr D.M., Huber S.C. (1991) Sucrose phosphate synthase and other sucrose metabolizing enzymes in fruits of various species. Physiologia Plantarum, 82, 191-196.

Koch K. (2004) Sucrose metabolism: regulatory mechanisms and pivotal roles in sugar sensing and plant development. Current Opinion in Plant Biology, 7, 235-246.

Komatsu A., Moriguchi T., Koyama K., Omura M., Akihama T. (2002) Analysis of sucrose synthase genes in citrus suggests different roles and phylogenetic relationships. Journal of Experimental Botany, 53, 61-71.

Kurepa J., Walker J.M., Smalle J., Gosink M.M., Davis S.J., Durham T.L., Sung D.Y., Vierstra R.D. (2003) The small ubiquitin-like modifier (SUMO) protein modification system in Arabidopsis. Journal of Biological Chemistry, 278, 6862-6872.

Ky C.L., Louarn J., Dussert S., Guyot B., Hamon S., Noirot M. (2001) Caffeine, trigonelline, chlorogenic acids and sucrose diversity in wild Coffea arabica L. and C. canephora P. accessions. Food Chemistry, 75, 223-230.

Leroy T., Marraccini P., Dufour M., Montagnon C., Lashermes P., Sabau X., Ferreira L.P., Jourdan I., Pot D., Andrade A.C., Glaszmann J.C., Vieira L.G.E., Piffanelli P. (2005) Construction and characterization of a Coffea canephora BAC library to study the organization of sucrose biosynthesis genes. Theoretical and Applied Genetics, 111, 1032-1041.

Leroy T., Ribeyre F., Bertrand B., Charmetant P., Dufour M., Montagnon C., Marraccini P., Pot D. (2006) Genetics of coffee quality. Brazilian Journal of Plant Physiology, 18, 229-242. 
Lingle S.E., Dunlap J.R. (1987) Sucrose metabolism in netted muskmelon fruit during development. Plant Physiology, 84, 386-389.

Lopes M.H.C. (1974) Caractéristiques chimiques et technologiques des cafés Racemosa du Mozambique. Café Cacao Thé, 18, 263-276.

Marraccini P., Rogers W.J., Allard C., André M.L., Caillet V., Lacoste N., Lausanne F., Michaux S. (2001) Molecular and biochemical characterization of endo- $\beta$-mannanases from germinating coffee (Coffea arabica) grains. Planta, 213, 296-308.

Mazzafera P. (1990) Metabolismo de cafeína em espécies de café (Coffea L.). PhD Thesis. University of Campinas, Campinas.

Mazzafera P., Magalhães A.C.N. (1991) Cafeína em folhas e sementes de espécies de Coffea e Paracoffea. Revista Brasileira de Botânica, 14, 157-160.

Mazzafera P., Crozier A., Magalhães A.C.N. (1991) Caffeine metabolism in Coffea arabica and other species of coffee. Phytochemistry, 30, 3913-3916.

McElfresh K.C., Chourey P.S. (1988) Anaerobiosis induces transcription but not translation of sucrose synthase in maize. Plant Physiology, 87, 542-546.

Mônaco L.C., Carvalho A. (1972) Incompatibilidade em Coffea racemosa. Ciência e Cultura, 24, 150-151.

Moriguchi T., Sananda T., Yamaki S. (1990) Seasonal fluctuations of some enzymes relating to sucrose and sorbitol metabolism in peach fruit. Journal of the American Society for Horticultural Science, 115, 278-281.

Rogers W.J., Michaux S., Bastin M., Bucheli P. (1999) Changes to the content of sugars, sugar alcohols, myoinositol, carboxylic acids and inorganic anions in developing grains from different varieties of Robusta (Coffea canephora) and Arabica (C. arabica) coffees. Plant Science, 149, 115-123.

Röhrig H., John M., Schmidt J. (2004) Modification of soybean sucrose synthase by S-thiolation with ENOD40 peptide A. Biochemical and Biophysical Research Communications, 325, 864-870.

Sambrook J., Fritsch E.F., Maniatis T. (1989) Molecular Cloning: a Laboratory Manual. 2nd edn. New York, NY, USA: Cold Spring Harbor Laboratory Press.

Silva H.L. (1956) Número de cromosommas em Coffea racemosa Lour. Bragantia, 15, 17-18.

Söndahl M.R., Baumann T.W. (2001) Agronomy II: developmental and cell biology. In Coffee: Recent Developments, pp. 202-223. Eds R.J. Clarke and O.G. Vitzthum. Oxford, UK: Blackwell Science.
Sturm A., Tang G.-Q. (1999) The sucrose-cleaving enzymes of plants are crucial for development, growth and carbon partitioning. Trends in Plant Science, 4, 401-407.

Taliercio E.W., Chourey P.S. (1989) Post-transcriptional control of sucrose synthase expression in anaerobic seedlings of maize. Plant Physiology, 90, 1359-1364.

Vaast P., Bertrand B., Perriot J.J., Guyot B., Génard M. (2006) Fruit thinning and shade improve bean characteristics and beverage quality of coffee (Coffea arabica L.) under optimal conditions. Journal of the Science of Food and Agriculture, 86, 197-204.

Vieira L.G.E., Andrade A.C., Colombo C.A., Moraes A.A.H., Metha A., Oliveira A.C., Labate C.A., Marino C.L., Monteiro-Vitorello C.B., Monte D.C., Giglioti E., Kimura E.T., Romano E., Kuramae E.E., Lemos E.G.M., Almeida E.R.P., Jorge E.C., Barros E.V.S.A., da Silva F.R., Vinecky F., Sawazaki H.E., Dorry H.F.A., Carrer H., Abreu I.N., Batista J.A.N., Teixeira J.B., Kitajima J.P., Xavier K.G., Lima L.M., Camargo L.E.A., Pereira L.F.P., Coutinho L.L., Lemos M.V.F., Romano M.R., Machado M.A., Costa M.M.C., Grossi de Sá M.F., Goldman M.H.S., Ferro M.I.T., Tinoco M.L.P., Oliveira M.C., Sluys M.A.V., Shimizu M.S., Maluf M.P., Eira M.T.S., Guerreiro Filho O., Arruda P., Mazzafera P., Mariani P.D.S.C., Oliveira R.L., Harakava R., Balbao S.F., Tsai S.M., Mauro S.M.Z., Santos S.N., Siqueira W.J., Costa G.G.L., Formighieri E.F., Carazzolle M.F., Pereira G.A.G. (2006) Brazilian coffee genome project: an EST-based genomic resource. Brazilian Journal of Plant Physiology, 18, 95-108.

Wang F., Sanz A., Brenner M.L., Smith A.G. (1993) Sucrose synthase, starch accumulation, and tomato fruit sink strength. Plant Physiology, 101, 321-327.

Wang F., Smith A.C., Brenner M.L. (1994) Temporal and spatial expression pattern of sucrose synthase during tomato fruit development. Plant Physiology, 104, 535-540.

Weber H., Borisjuk L., Wobus U. (1997) Sugar import and metabolism during seed development. Trends in Plant Science Research, 2, 169-174.

Winter H., Huber S.C. (2000) Regulation of sucrose metabolism in higher plants: localization and regulation of activity of key enzymes. Critical Reviews in Plant Sciences, $19,31-67$.

Wormer T.M. (1964) The growth of the coffee berry. Annals of Botany, 28, 47-55. 